\title{
Nanoparticle-Mediated Intervalence Transfer
}

\author{
Wei Chen,${ }^{\dagger}$ Shaowei Chen, ${ }^{\dagger *}$ Feizhi Ding, ${ }^{\ddagger}$ Haobin Wang, ${ }^{\dagger *}$ Lauren E. Brown, ${ }^{\dagger}$ and Joseph P. \\ Konopelski ${ }^{\dagger}$
}

${ }^{\dagger}$ Department of Chemistry and Biochemistry, University of California, Santa Cruz, CA 95064

* Department of Chemistry and Biochemistry, New Mexico State University, Las Cruces, NM 88003

*To whom all correspondence should be addressed.E-mail: schen@chemistry.ucsc.edu (S.W.C.), andHaobin@nmsu.edu (H.B.W.)

\section{Complete References for 23 and 28}

23. Frisch, M. J.; Trucks, G.W.; Schlegel, H.B.; Scuseria, G.E.; Robb, M.A.; Cheeseman, J.R.; Montgomery, J.A., Jr.; Vreven, T.; Kudin, K.N.; Burant, J.C.; Millam, J.M.; Iyengar, S.S.; Tomasi, J.; Barone, V.; Mennucci, B.; Cossi, M.; Scalmani, G.; Rega, N.; Petersson, G.A.; Nakatsuji, H.; Hada, M.; Ehara, M.; Toyota, K.; Fukuda, R.; Hasegawa, J.; Ishida, M.; Nakajima, T.; Honda, Y.; Kitao, O.; Nakai, H.; Klene, M.; Li, X.; Knox, J.E.; Hratchian, H.P.; Cross, J.B.; Bakken, V.; Adamo, C.; Jaramillo, J.; Gomperts, R.; Stratmann, R.E.; Yazyev, O.; Austin, A. J.; Cammi, R.; Pomelli, C.; Ochterski, J.W.; Ayala, P.Y.; Morokuma, K.; Voth, G.A.; Salvador, P.; Dannenberg, J.J.; Zakrzewski, V.G.; Dapprich, S.; Daniels, A.D.; Strain, M.C.; Farkas, O.; Malick, D.K.; Rabuck, A.D.; Raghavachari, K.; Foresman, J.B.; Ortiz, J.V.; Cui, Q.; Baboul, A.G.; Clifford, S.; Cioslowski, J.; Stefanov, B.B.; Liu, G.; Liashenko, A.; Piskorz, P.; Komaromi, I.; Martin, R.L.; Fox, D.J.; Keith, T.; Al-Laham, M.A.; Peng, C.Y.; Nanayakkara, A.; Challacombe, M.; Gill, P.M.W.; Johnson, B.; Chen, W.; Wong, M. W.; Gonzalez, C.; Pople, J. A. Gaussian, Inc.: Wallingford, CT, 2004.

28. Bylaska, E. J.; de Jong, W.A.; Kowalski, K.; Straatsma, T.P.; Valiev, M.; Wang, D.; Aprà, E.; Windus, T.L.; Hirata, S.; Hackler, M.T.; Zhao, Y.; Fan, P.-D.; Harrison, R.J.; Dupuis, M.; Smith, D.M.A.; Nieplocha, J.; Tipparaju, V.; Krishnan, M.; Auer, A.A.; Nooijen, M.; Brown, E.; Cisneros, G.; Fann, G.I.; Früchtl, H.; Garza, J.; Hirao, K.; Kendall, R.; Nichols, J.; Tsemekhman, K.; Wolinski, K.; Anchell, J.; Bernholdt, D.; Borowski, P.; Clark, T.; Clerc, D.; Dachsel, H.; Deegan, M.; Dyall, K.; Elwood, D.; Glendening, E.; Gutowski, M.; Hess, A.; Jaffe, J.; Johnson, B.; Ju, J.; Kobayashi, R.; Kutteh, R.; Lin, Z.; Littlefield, R.; Long, X.; Meng, B.; Nakajima, T.; Niu, S.; Rosing, M.; Sandrone, G.; Stave, M.; Taylor, H.; Thomas, G.; van Lenthe, J.; Wong, A.; Zhang, Z., Pacific Northwest National Laboratory, Richland, Washington 99352-0999, 2006. 


\section{Additional Experimental Data}

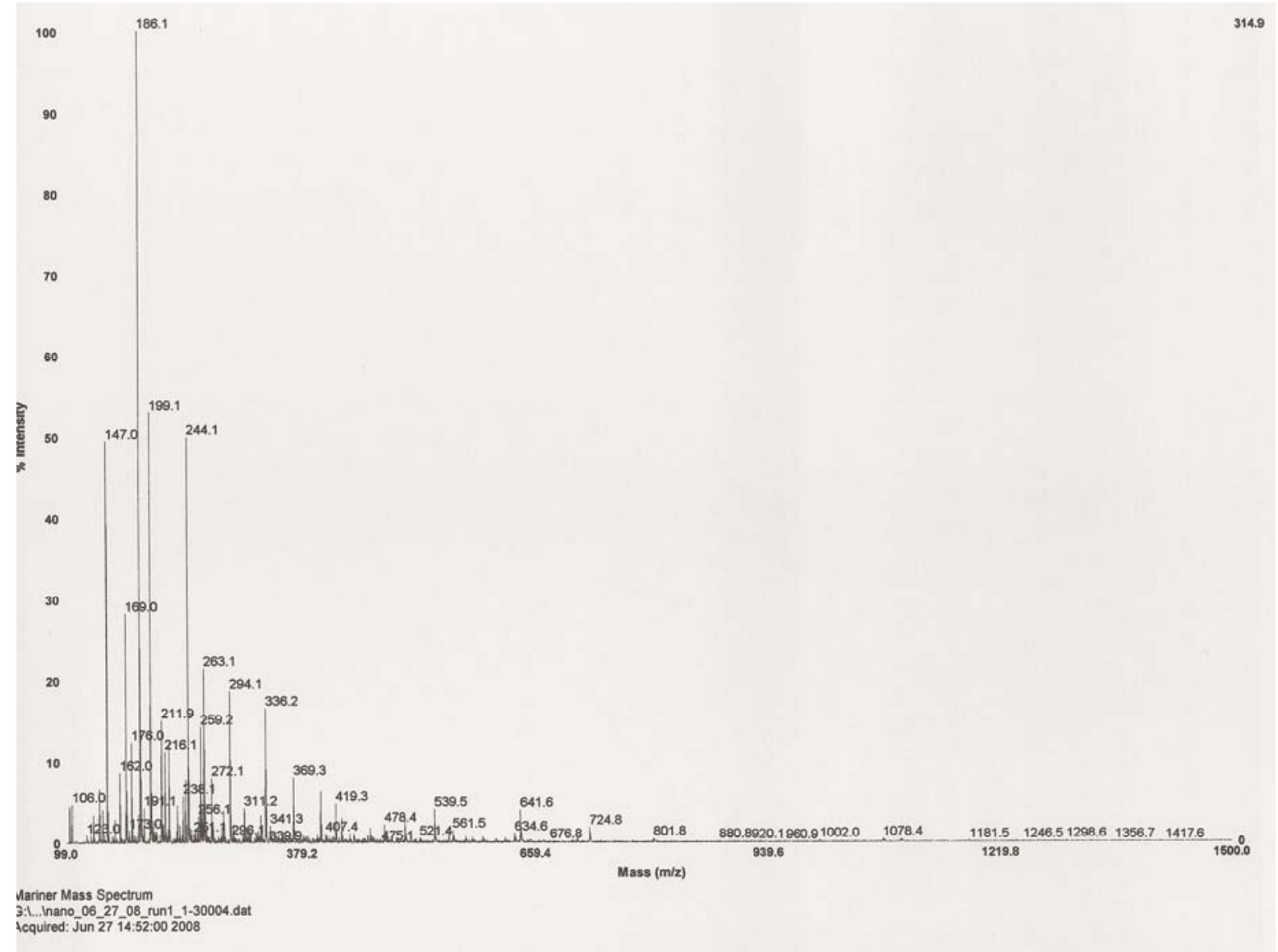

Figure S1 Mass spectrum of the organic extract after the dissolution of the $\mathrm{Ru}=\mathrm{CH}-\mathrm{Fc}$ particle cores by dilute KCN. Note that while the exact chemical structures of the organic products are somewhat unclear at the moment, the mass spectrometric measurements did suggest the formation of (i) heterodimers of the carbene and ferrocene fragments $(\mathrm{m} / \mathrm{z} 369.3)$, (ii) ketenimine derivatives of the carbene fragments (m/z 199.1), as well as (iii) derivatives of ferrocene $(\mathrm{m} / \mathrm{z}$ 186.1 and 211.9). Of these, both (i) and (ii) lead to the appearance of a singlet at $4.74 \mathrm{ppm}$ for the methine proton in the NMR measurements (Figure 1) as well as a modestly intense band at $2109 \mathrm{~cm}^{-1}$ in the FTIR measurements. ${ }^{1}$ No polymeric products were detected in mass spectrometric measurements. 


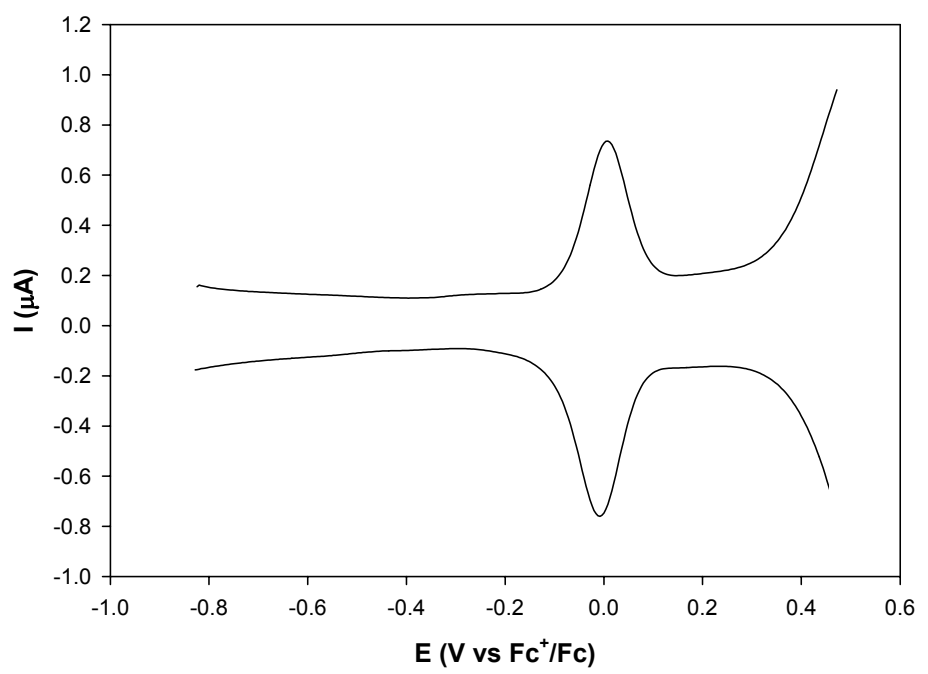

Figure S2 SWV of the organic components of $\mathrm{Ru}=\mathrm{CH}-\mathrm{Fc}$ nanoparticles (sample III) collected after the dissolution of the Ru core by dilute KCN (same as those used in Figure 1 for NMR study and Figure S1 for mass spec measurements). The sample was dissolved in DMF with 0.1 M TBAP. The appearance of only one pair of voltammetric peaks suggests that the ferrocene moieties exist as individual ligands, rather than in a polymeric form, on the nanoparticle surface, in good agreement with the mass spec results (Figure S1). Note that in polyvinylferrocene thin films, ${ }^{2}$ the splitting of voltammetric peaks may occur; but the splitting is typically around 100 $\mathrm{mV}$, significantly smaller than what we observed here with the $\mathrm{Ru}=\mathrm{CH}-\mathrm{Fc}$ nanoparticles.

\section{Theoretical Calibration}

Additional theoretical studies were carried out to compare to the experiments in a more quantitative fashion. First, we carried out CDFT calculations of the reference system of biferrocene monocation $[\mathrm{Fc}-\mathrm{Fc}]^{+}$in $\mathrm{CH}_{2} \mathrm{Cl}_{2}$, where the solvent effects are described by the conductor-like screening model (COSMO) implemented in NWCHEM. The theoretical value for nonadiabatic electronic coupling $\left(\mathrm{H}_{\mathrm{AB}}\right)$ was found to be approximately $710 \mathrm{~cm}^{-1}$, in quite good agreement with that from time-dependent analysis of resonance Raman scattering $\left(900 \mathrm{~cm}^{-1}\right)$ by Hupp and coworkers. ${ }^{3}$ The Robin-Day interaction parameter $\left(\alpha^{2}\right)$ was then estimated from $\mathrm{H}_{\mathrm{AB}}$ for biferrocene monocation in acetonitrile by approximating $\bar{v}_{\max }=\lambda$ (solvent reorganization energy $\sim 4950 \mathrm{~cm}^{-1}$ in acetonitrile), and we obtained $\alpha^{2}=0.02$, which is also close to the experimental value of $0.01 .^{4} \mathrm{Next}$, we performed calculations of a series of diferrocenylpolyene monocations $\left[\mathrm{Fc}-(\mathrm{CH}=\mathrm{CH})_{\mathrm{n}}-\mathrm{Fc}\right]^{+}$in $\mathrm{CH}_{2} \mathrm{Cl}_{2}$. At $\mathrm{n}=1$ and 6 , the electronic coupling was found to be $0.082 \mathrm{eV}$ and $0.029 \mathrm{eV}$, respectively, in close agreement with the experimental estimates of $0.061 \mathrm{eV}$ and $0.022 \mathrm{eV} .^{5}$ In essence, we observed an exponential decay of the coupling versus distance, similar to that observed experimentally. ${ }^{5}$

\section{References}

(1) Fulloon, B.; Elnabi, H. A. A.; Kollenz, G.; Wentrup, C. Tetrahedron Letters 1995, 36, 6547-6550.

(2) Peerce, P. J.; Bard, A. J. Journal of Electroanalytical Chemistry 1980, 114, 89-115.

(3) Williams, R. D.; Petrov, V. I.; Lu, H. P.; Hupp, J. T. Journal of Physical Chemistry A 1997, 101, 8070-8076.

(4) Brunschwig, B. S.; Creutz, C.; Sutin, N. Chemical Society Reviews 2002, 31, 168-184.

(5) Ribou, A. C.; Launay, J. P.; Sachtleben, M. L.; Li, H.; Spangler, C. W. Inorganic Chemistry 1996, 35, $3735-$ 3740. 


\section{Additional Computational Data}

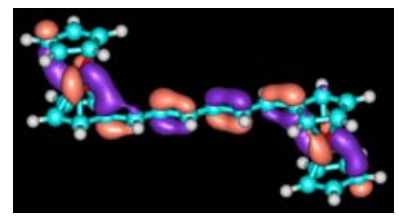

Figure S3. HOMO topology of $\mathrm{Fc}(\mathrm{CH}=\mathrm{CH})_{3} \mathrm{Fc}$ monocation. The charge delocalization can be seen over the entire molecule. Similar behaviors were observed with monocations of other $\mathrm{Fc}(\mathrm{CH}=\mathrm{CH})_{\mathrm{nFc}}$ derivatives.
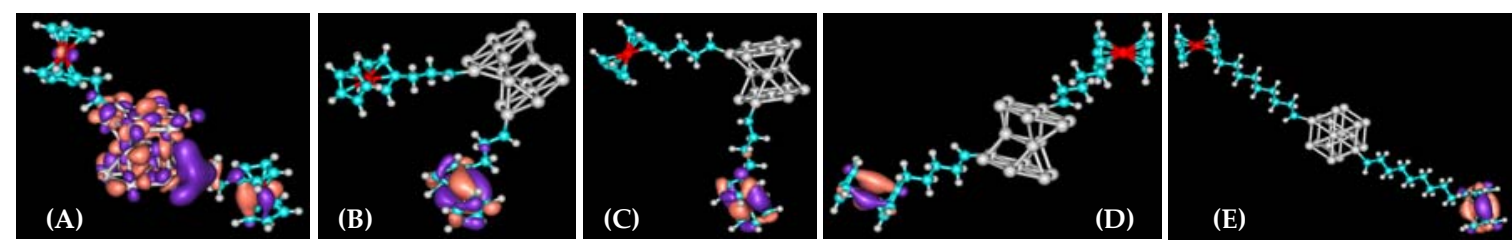

Figure S4. HOMO topological diagrams for monocations of a series of Ru17 $\left[=\mathrm{CH}-\left(\mathrm{CH}_{2}\right)_{\mathrm{n}}-\mathrm{Fc}_{2} \mathrm{cluster}\right.$ models: (A) Ru17 $\left[=\mathrm{CH}-\mathrm{CH}_{2}-\mathrm{Fc}\right]_{2}$; (B) $\mathrm{Ru}_{17}\left[=\mathrm{CH}-\mathrm{CH}_{2}-\mathrm{CH}_{2}-\mathrm{Fc}\right]_{2} ;(\mathrm{C}) \mathrm{Ru}_{17}\left[=\mathrm{CH}-\mathrm{CH}_{2}-\mathrm{CH}_{2}-\mathrm{CH}_{2}-\mathrm{Fc}_{2}\right.$; (D) $\mathrm{Ru}_{17}\left[=\mathrm{CH}-\mathrm{CH}_{2}-\mathrm{CH}_{2}-\mathrm{CH}_{2}-\mathrm{CH}_{2}-\mathrm{Fc}\right]_{2}$; (E) $\mathrm{Ru}{ }_{17}\left[=\mathrm{CH}-\left(\mathrm{CH}_{2}\right)_{8}-\mathrm{FC}\right]_{2}$. As shown in panel (A), at $\mathrm{n}=1$, the $\mathrm{HOMO}$ is already partially localized on one of the $\mathrm{FC}$ moieties, indicating weakened electronic communication as compared to that observed in Figure 4 (A). For longer spacers, i.e., $\mathrm{n} \geq 2$ (panels B - E), the HOMOs are completely localized on one of the Fc moieties, suggesting class I characteristics with no intervalence transfer. These behaviors are in good agreement with the experimental data presented in Figures 2 and 3 with the $\mathrm{Ru}=\mathrm{CH}-\mathrm{CH}_{2}-\mathrm{Fc}$ nanoparticles.
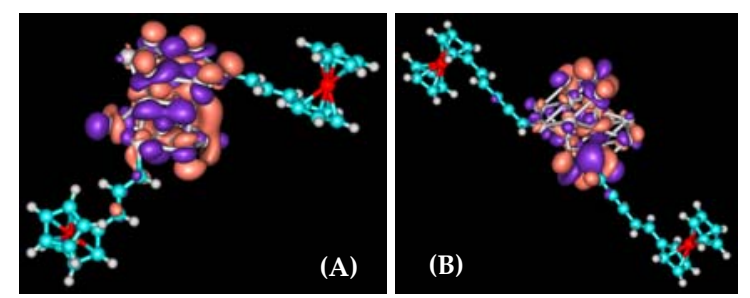

Figure S5. HOMO topological diagrams for monocations of $(\mathrm{A}) \mathrm{Ru}_{17}[=\mathrm{CH}-\mathrm{CH}=\mathrm{CH}-\mathrm{Fc}]_{2}$; and $(\mathrm{B}) \mathrm{Ru}_{17}[=\mathrm{CH}-$ $\mathrm{C} \equiv \mathrm{C}-\mathrm{CH}=\mathrm{CH}-\mathrm{Fc}]_{2}$. The features of charge delocalization are similar to those in Figure 4 (A). 